\title{
Pelaksanaan Inisiasi Menyusu Dini Sebagai Upaya Memperlancar Pemberian ASI Eksklusif
}

\author{
Juliana Widyastuti Wahyuningsih \\ Akademi Kebidanan Budi Mulia Palembang
}

Informasi Artikel :

Diterima : 10 Oktober 2020

Direvisi : 20 Oktober 2020

Disetujui : 03 November 2020

*Korespondensi Penulis :

yuliana_widyastuti@ymail.com

\section{A B S T R A K}

Salah satu asuhan yang diberikan bidan adalah asuhan pada bayi baru lahir. Protokol evidence-based yang baru telah diperbaharui oleh WHO dan UNICEF tentang asuhan bayi baru lahir untuk satu jam pertama yang menyatakan bahwa bayi harus mendapatkan kontak kulit dengan ibunya segera setelah lahir selama paling sedikit satu jam. Inisiasi Menyusu Dini (early intitiation) atau permulaan menyusu dini adalah bayi mulai menyusu sendiri segera setelah lahir. Penelitian ini bertujuan untuk mengetahui "Pelaksanaan Inisiasi Menyusu Dini Sebagai Upaya Memperlancar Pemberian ASI Eksklusif Di Klinik Bersalin Budi Mulia Medika Palembang. Desain penelitian ini menggunakan metode Action Recearch yaitu peneliti melakukan asuhan atau pelaksanaan secara langsung pada klien, dimana pengambilan sampel menggunakan metode accidental sampling yaitu cara pengambilan sampel yang dilakukan dengan kebetulan bertemu dan teknik pengumpulan data menggunakan check list . Populasi dalam penelitian ini adalah semua ibu bersalin yang melakukan Inisiasi Menyusu Dini di Klinik Bersalin Budi Mulia Medika Palembang dari Bulan September Tahun 2020. Sampel pada penelitian ini adalah ibu bersalin yang bersedia untuk melakukan IMD dan bayi yang dapat dilakukan IMD yang memiliki berat badan $>2500$ gram, atau bayi yang tidak mengalami asfiksia di Klinik Bersalin Budi Mulia Medika Palembang. Pelaksanaan Inisiasi Menyusu Dini dapat memperlancar pemberian ASI Eksklusif pada bayi. Karena segera setelah lahir bayi telah dibiasakan diberi ASI dan ASI dapat memenuhi kebutuhan makanannya yang paling lengkap tanpa diberikan makanan tambahan lain sehingga berat badan bayi pun akan lebih cepat bertambah.

\section{Kata Kunci : Inisiasi Menyusu Dini, ASI Eksklusif}

\section{ABSTRACT}

One of the care that midwives provide is care for newborns. A new evidence-based protocol has been updated by WHO and UNICEF on newborn care for the first hour that states that the infant should have skin contact with the mother immediately after birth for at least one hour. Early initiation of breastfeeding (early initiation) or early initiation of breastfeeding is the baby starts to breastfeed itself immediately after birth. This study aims to determine "Implementation of Early Initiation of Breastfeeding as Efforts to Streamline Exclusive Breastfeeding at the Budi Mulia Medika Maternity Clinic, Palembang. The design of this study uses the Action Recearch method, namely the researcher carries out care or implementation directly to the client, where the sampling uses the accidental sampling method, namely the sampling method which is done by chance meeting and the data collection technique uses a check list. The population in this study were all maternity mothers who performed Early Breastfeeding Initiation at the Budi Mulia Medika Maternity Clinic in Palembang September 2020. The 
sample in this study were mothers who were willing to perform IMD and babies who could be performed IMD who had weight> 2500 grams, or babies who do not experience asphyxia at the Budi Mulia Medika Maternity Clinic in Palembang. Early Initiation of Breastfeeding can facilitate exclusive breastfeeding for babies. Because immediately after birth the baby is accustomed to being breastfed and breast milk can meet their most complete dietary needs without being given other additional foods so that the baby's weight will increase faster.

\section{Keywords: Early Initiation of Breastfeeding, Exclusive Breastfeeding}

\section{PENDAHULUAN}

Salah satu asuhan yang diberikan bidan adalah asuhan pada bayi baru lahir. Protokol evidence-based yang baru telah diperbaharui oleh WHO dan UNICEF tentang asuhan bayi baru lahir untuk satu jam pertama yang menyatakan bahwa bayi harus mendapatkan kontak kulit dengan ibunya segera setelah lahir selama paling sedikit satu jam, yang kedua bayi harus dibiarkan untuk melakukan inisiasi menyusu dini dan ibu dapat mengenal bahwa bayinya siap untuk menyusu serta memberi bantuan jika diperlukan, dan yang ketiga menunda semua prosedur lainnya yang harus dilakukan kepada bayi baru lahir hingga inisiasi menyusu selesai dilakukan, prosedur tersebut seperti memandikan, menimbang, pemberian vitamin $\mathrm{K}$, salep mata, dan lain- lain.(JNPK- KR, 2007).

Menurut Riset Kesehatan Dasar (Riskesdas) Tahun 2013, persentase tertinggi proses mulai menyusu pada anak umur 0-23 bulan adalah pada 1-6 jam $(35,2 \%)$. Proses mulai menyusu pada satu jam pertama setelah lahir/IMD hanya $34,5 \%$. IMD mengalami peningkatan pada tahun 2018. Berdasarkan hasil Riskesdas tahun 2018, proporsi IMD pada anak umur 0-23 bulan adalah 58,2\%. Dari proporsi ini, yang melakukan IMD $\geq 1$ jam hanya $15,9 \%$.

Berdasarkan provinsi, persentase tertinggi bayi baru lahir mendapat IMD tahun 2017 adalah Provinsi Aceh (97,31\%), sedangkan persentase terendah adalah Provinsi Papua (15\%). Untuk Sumatera Selatan sendiri Presentasi Bayi Baru Lahir Mendapat IMD adalah 74,49 \%. Jika melihat data yang ada, pelaksanaan IMD erat kaitannya dengan daerah tempat tinggal dan akses masyarakat kepada pelayanan kesehatan(Direktrat Jenderal Kesehatan Masyarakat, 2018).

Jumlah ibu bersalin yang melakukan IMD di Klinik Bersalin Budi Mulia Medika Palembang pada tahun 2019 berjumlah 75 orang per 77 kelahiran hidup, pada rentan waktu bulan Januari hingga September tahun 2020 tercatat jumlah ibu bersalin 38 orang per 40 kelahiran hidup.

IMD dapat menyelamatkan $22 \%$ dari bayi yang meninggal sebelum usia 1 bulan. Selain itu, dengan melakukan IMD, pemberian ASI ekslusif terlaksana dan lama menyusui lebih panjang sehingga kebutuhan gizi bayi terpenuhi. Jika bayi dapat menyusu 1 jam pertama setelah kelahiran dapat menyelamatkan $22 \%$ bayi dan jika menyusu pada hari pertama akan menyelamatkan $16 \%$ bayi. Jadi, bayi akan meningkat spesifik jika permulaan menyusu ditinggalkan (Handy, 2011 ).

Dikarenakan pentingnya Inisiasi Menyusui Dini untuk menurunkan angka kematian bayi dan memperlancar pemberian ASI Eksklusif, maka penulis tertarik untuk melakukan penelitian tentang "Pelaksanaan Inisiasi Menyusu Dini Sebagai Upaya Memperlancar Pemberian ASI Eksklusif Di Klinik Budi Mulia Medika Palembang".

\section{METODE PENELITIAN}

Desain penelitian ini menggunakan metode Action Recearch yaitu peneliti melakukan asuhan atau pelaksanaan secara langsung pada klien. Penelitian action research adalah bertujuan untuk mencari sampel perencanaan, tindakan, pengamatan, refleksi, dimana besar sampel dalam penelitian ini difokuskan pada ibu bersalin untuk dirawat dan dilakukan penatalaksanaan secara komprehensif mulai dari perencanaan, tindakan, pengamatan sampai refleksi/ hasil dari penatalaksanaan.

Populasi dalam penelitian ini adalah seluruh ibu yang bersalin di Klinik Budi Mulia Medika Palembang Tahun 2020. Pengambilan sampel yang akan dilakukan pada penelitian ini dengan metode Accidental sampling yaitu cara pengambilan sampel yang dilakukan dengan kebetulan bertemu. Sebagai contoh, dalam menentukan sampel apabila dijumpai ada, maka sampel tersebut diambil dan langsung dijadikan sebagai sampel utama. Penelitian Action research adalah bertujuan untuk mencari sampel perencanaan, tindakan, pengamatan, dan refleksi. 
Dimana besar sampel dalam penelitian ini difokuskan hanya pada 1 sampel, hal ini dikarenkan keterbatasan waktu penelitian.

Pengumpulan data dapat dilakukan dengan cara mengobservasi langsung, dan menyusun sekumpulan informasi kemudian setelah data dikumpulkan lakukan analisis untuk mendukung alur diagnosis kerja namun bukan proses yang pembuatannya linier atau secara satu garis lurus melainkan proses yang sirkuler (terus-menerus), untuk membuat diagnosis dan identifikasi masalah diperlukan data yang lengkap dan akuran serta kemampuan untuk menginterpretasi/analisa data, setelah itu menentukan rumusan masalah yang terkait langsung maupun tidak langsung terhadap diagnosis tetapi dapat pula merupakan masalah utama yang saling terkait, kemudian mengenali kebutuhan terhadap tindakan segera sebagai langkah pemberian asuhan, menyusun rencana asuhan atau intervensi melalui kajian data yang telah diperoleh, identifikasi kebutuhan atau kesiapan asuhan dan intervensi mengukur sumberdaya atau kemampuan yang dimiliki. Setelah membuat rencana asuhan, laksanakan rencana tersebut secara tepat waktu dan aman, penatalaksanaan yang telah dikerjakan kemudian dievaluasi untuk menilai efektivitasnya, tentukan bila perlu dikaji ulang atau diteruskan sesuai rencana kebutuhan dalam pengolahan data.

\section{HASIL PENELITIAN}

\section{Pelaksanaan Inisiasi Menyusu Dini a. Persiapan Klien}

Peneliti menjelaskan kepada klien tentang Inisiasi Menyusu Dini, dan sebaiknya pemberian ASI adalah dimulai sedini mungkin dan secara eksklusif segera setelah bayi lahir.

Adapun hasil wawancara yang dilakukan kepada klien adalah sebagai berikut:" Saya mau menyusui anak saya langsung saat dia lahir, karena bagi saya memberikan ASI untuk anak itu penting 3 anak saya juga dilakukan Inisiasi Menyusu Dini dan diberikan ASI ekkslusif. Sehingga saya ingin melakukannya"

Kemudian peneliti menjelaskan keuntungan, kerugian dilakukannya Inisiasi Menyusu Dini yaitu sebagai berikut :" Inisiasi Menyusu Dini memang sangat baik dilakukan dan tidak mengganggu produksi ASI, justru meningkatkan produksi ASI selain itu Inisiasi Menyusu Dini juga memiliki keuntungan bagi bayi dan ibu, yaitu dapat meningkatkan kecerdasan bayi, mencegah kehilangan panas pada bayi, memberikan kekebalan pasif yang segera kepada bayi, makanan dengan kualitas dan kuantitas optimal agar kolostrum segera keluar yang disesuaikan dengan kebutuhan bayi, merangsang kolostrum segera keluar, meningkatkan keberhasilan produksi ASI, membantu agar perdarahan pasca persalinan lebih rendah, mengurangi stres pada ibu, serta meningkatkan jalinan kasih sayang ibu dan bayi. Inisiasi Menyusu Dini ini dilakukan segera setelah bayi lahir selama $l$ jam. Setelah dilakukannya Inisiasi Menyusu Dini ibu lanjutkan dengan memberikan ASI eksklusif."

Peneliti memberitahukan kepada klien waktu yang tepat untuk melakukan Inisiasi Menyusu Dini yaitu: “Jadi Inisiasi Menyusu Dini 2dilakukan pada saat ibu mau melahirkan nanti segera setelah bayi lahir kita lakukan Inisiasi Dini selama kurang lebih 1 jam ya buk. Baiklah pada saat setelah melahirkan saya ingin melakukan Inisiasi Menyusu Dini"

Pada saat klien sudah waktunya ingin melahirkan yaitu pada tanggal 10 September 2020 klien mendatangi Klinik Budi Mulia Medika Palembang untuk melakukan persalinan sekaligus melakukan Inisiasi Menyusu Dini. Kemudian peneliti melakukan anamnesa kepada klien.

Sebelum di lakukan IMD peneliti telah menyiapkan alat, observer, check list dan ruangan. Peneliti melakukan Senyum, sapa dan salam kepada ibu terlebih dahulu,lalu melakukan cuci tangan secara efektif sebelum membantu ibu melakukan IMD. Kemudian peneliti memasang alat perlindungan diri sebelum melakukan tindakan. Sebelumnya meminta persetujuan terlebih dahulu kepada ibu untuk dilakukan IMD. Dimulai setelah bayi lahir meletakkan bayi di perut ibu, lalu menilai bayi apakah diperlukan resusitasi atau tidak ( 2 detik), Bila tidak perlu resusitasi, mengeringkan tubuh bayi mulai dari muka, kepala, dan bagian tubuh lainnya dengan halus kecuali tangan karena bau cairan amnion pada tangan bayi membantunya mencari puting ibunya yang berbau sama. Setelah itu, menyelimuti bayi dengan kain kering untuk menunggu 2 menit sebelum tali pusat di klem. Menghindari mengeringkan tangan bayi, lendir cukup di lap dengan kain bersih, penghisapan tidak dilakukan karena dapat merusak selaput lendir dan dapat meningkatkan resiko infeksi pernafasan. Meletakkan bayi tengkurap didada ibu, luruskan bahu bayi sehingga bayi menempel di dada ibu langsung dengan melakukan kontak kulit ke kulit, luruskan bahu bayi sehingga bayi menempel di dada ibu, tapi lebih rendah dari puting. Kemudian menyelimuti ibu dan bayi dengan kain hangat dan pasang topi di kepala bayi. Biarkan bayi tetap melakukan kontak kulit 
ke kulit di dada ibu paling sedikit 1 jam, mintalah ibu untuk memeluk dan membelainya bayinya. Lalu meletakkan bantal dibawah kepala ibu untuk mempermudah kontak visual antara ibu dan bayi. Bayi memperlihatkan perilaku dalam 30 menit pertama diam tidak bergerak dan matanya membuka lebar,pada 35 menit bayi mengeluarkan suara, mulut seperti ingin minum, mencium, dan menjilat tangan lalu mengeluarkan air liur, 45 menit bayi mulai bergerak kearah payudara ibu, saat menemukan, menjilat, mengulum puting dan mulutnya membuka lebar dan melekaat dengan baik, serta posisi bayi benar, kemudian bayi menyusui selama 10 menit lalu berhenti menyusu, posisi bayi saat menyusu dalam keadaan benar. Kemudian saat ibu melakukan IMD peneliti memperhatikan kondisi ibu dan bayi yang terlihat tenang dan nyaman. Sehingga memudahkan peneliti dan observer melakukan penilaian.

Setelah selesai dilakukan Inisiasi Menyusu Dini selama 55 menit, peneliti memberitahukan kepada ibu bahwa IMD selesai dilakukan dan bayinya akan dilakukankan asuhan bayi baru lahir normal. Peneliti membereskan alat dan perlengkapan lainnya.

\section{Evaluasi}

Setelah dilakukan inisiasi menyusu dini klien merasa tenang dengan memeluk bayinya, dan kolostrum mulai keluar,bayi juga memperlihatkan perilaku dalam 30 menit pertama diam tidak bergerak dan matanya membuka lebar,pada 35 menit bayi mengeluarkan suara, mulut seperti ingin minum, mencium, dan menjilat tangan lalu mengeluarkan air liur, 45 menit bayi mulai bergerak kearah payudara ibu, saat menemukan, menjilat, mengulum puting dan mulutnya membuka lebar dan melekat dengan baik, serta posisi bayi benar saat dilakukannya inisiasi menyusu dini, kemudian bayi menyusui selama 10 menit lalu berhenti menyusu. Kemudian peneliti memberitahukan beberapa perawatan payudara setelah Inisiasi Menyusu Dini kepada ibu yaitu:

"Melanjutkan pemberian ASI setiap 2 jam sekali dan diberikan secara eksklusif tanpa memberikan makanan tambahan lainnya dan membersihkan payudara sebelum menyusui bayi. Saya akan melakukan kunjungan kerumah ibu setelah 1 minggu untuk melakukan pemeriksaan kembali."'

Pada hari ke-3 setelah dilakukannya IMD, peneliti melakukan pemeriksaan:

"Saya merasa masih sedikit ASI yang keluar, tapi saya tetap memberikan ASI secara eksklusif tanpa mengganti dengan makanan tambahan lainnya, berat badan bayi saya pun bertambah dari 3000 gram menjadi 3250 gram ." Kemudian peneliti dan observer memeriksa klien, produksi ASI lancar. Setelah 1 minggu, peneliti melakukan kunjungan rumah yaitu: "Sekarang produksi ASI saya semakin bertambah banyak, saya tetap memberikan ASI secara eksklusif ,dan pada saat imunisasi kemarin saat ditimbang berat badan bayi saya juga sudah semakin bertambah dari 3350 gram menjadi 3400 gram."

\section{PEMBAHASAN}

Penelitian ini dilakukan untuk sebagai upaya memperlancar pemberian ASI ekslusif. Penelitian ini dilakukan pada bulan September di Klinik Bersalin Budi Mulia Medika Palembang. Adapun sampel dalam penelitian ini adalah ibu yang melakukan Inisiasi Menyusu Dini dengan bayi berat $>2500$ gram.

\section{Pelaksanaan Inisiasi Menyusu Dini (IMD) a. Persiapan Klien}

Pada persiapan klien diketahui bahwa alasan klien melakukan Inisiasi Menyusu Dini adalah karena pada anak sebelumnya telah melakukan Inisiasi Menyusu Dini dan melakukan pemberian ASI eksklusif. Hal ini sesuai dengan tujuan peneliti yaitu untuk memperlancar pemberian ASI eksklusif. Menurut Khairuniyah (2004) ASI adalah makanan bayi yang paling penting terutama pada bulan-bulan pertama kehidupan. ASI merupakan sumber gizi yang sangat ideal dengan komposisi yang seimbang dan sesuai dengan kebutuhan pertumbuhan bayi, karena ASI adalah makanan bayi yang paling sempurna baik secara kualitas maupun kuantitas. ASI sebagai makanan tunggal akan cukup memenuhi kebutuhan tumbuh kembang bayi normal sampai usia 4-6 bulan.

Selain alasan klien, peneliti menjelaskan tentang Manfaat Inisiasi Menyusu Dini Menurut Anik Maryunani (2012) manfaat Inisiasi Menyusu Dini dapat dijelaskan secara umum dan khusus yaitu: Manfaat Inisiasi Menyusu Dini Secara Umum 1) Mencegah hipotermia karena dada ibu menghangatkan bayi dengan tepat selama bayi merangkak mencari payudara. 2) Bayi dan ibu menjadi lebih tenang, tidak stres, pernapasan dan detak jantung lebih stabil, dikarenakan oleh kontak antara kulit ibu dan bayi. 3) Imunisiasi Dini. Mengecap dan menjilat permukaan kulit ibu sebelum mulai mengisap puting adalah cara alami bayi mengumpulkan bakteri-bakteri baik yang ia perlukan untuk membangun sistem kekebalan tubuhnya. 
Manfaat Inisiasi Menyusu Dini Secara Khusus 1) Manfaat untuk Ibu a) Meningkatkan hubungan khusus ibu dan bayi b) Merangsang kontraksi otot rahim sehingga mengurangi resiko perdarahan sesudah melahirkan c) Memperbesar peluang ibu untuk memantapkan dan melanjutkan kegiatan menyusui selama masa bayi d) Mengurangi stres ibu setelah melahirkan e) Mencegah kehamilan f) Menjaga kesehatan ibu 2) Manfaat untuk Bayi a) Mempertahankan suhu bayi tetap hangat b) Menenangkan ibu dan bayi serta meregulasi pernafasan dan detak jantung c) Kolonisasi bakteri dan usus bayi dengan bakteri badan ibu yang normal (bakteri yang berbahaya dan menjadikan tempat yang baik bagi bakteri yang menguntungkan) dan mempercepat pengeluaran kolostrum sebagai antibody bayi.

Manfaat secara Psikologis 1) Adanya ikatan emosi (emotional bonding) a) Hubungan ibu - bayi lebih erat dan penuh kasih sayang. b) Ibu merasa lebih bahagia. c) Bayi lebih jarang menangis. d) Ibu berperilaku lebih peka (affectionately). e) Lebih jarang menyiksa bayi (child abused). 2) Perkembangan: anak menunjukkan uji kepintaran yang lebih baik di kemudian hari.

Prinsip Dasar IMD adalah cukup mengeringkan tubuh bayi yang baru lahir atau handuk tanpa harus memandikan, tidak membedong bayi, kemudian meletakkannya ke dada ibu dalam keadaan tengkurap sehingga ada kontak kulit dengan ibu, selanjutnya beri kesempatan bayi untuk menyusu sendiri pada ibu pada satu jam pertama kelahiran bayi.

\section{b. Persiapan Alat}

Pada Penelitian ini peneliti menyiapkan alat - alat yang akan digunakan untuk melakukan metode Inisiasi Menyusu Dini yaitu Ruangan tempat bersalin yang akan dipakai untuk dilakukannya Metode Inisisasi Menyusu Dini beserta selimut, kain bersih, handuk bersih, topi bayi, APD lengkap.

Menurut JNPK-KR (2008) alat - alat yang akan digunakan untuk melakukan metode Inisiasi Menyusu Dini yaitu Ruangan tempat bersalin yang akan dipakai untuk dilakukannya Metode Inisisasi Menyusu Dini beserta selimut, bantal, kain bersih, handuk bersih, topi bayi, APD lengkap.

Pada penelitian ini peneliti menggunakan observer yang bertugas mengobservasi peneliti pada waktu peneliti melakukan metode Inisiasi Menyusu Dini pada klien. Disini observer menggunakan check list untuk mengetahui letak kesalahan atau kekurangan yang dilakukan oleh peneliti, dinilai dengan cara dikerjakan dan tidak dikerjakan. Oleh karena itu sebelum penelitian dilakukan, peneliti telah menyiapkan check list yang akan digunakan oleh observer.

\section{c. Pelaksanaan Inisiasi Menyusu Dini (IMD)}

Inisiasi Menyusu Dini (early intitiation) atau permulaan menyusu dini adalah bayi mulai menyusu sendiri segera setelah lahir. Cara bayi melakukan Inisiasi Menysui Dini ini dinamakan the breast crawl atau merangkak mencari payudara Sitti Saleha, 2009).

Sebelum di lakukan IMD peneliti telah menyiapkan alat, observer, check list dan ruangan. Peneliti melakukan Senyum, sapa dan salam kepada ibu terlebih dahulu,lalu melakukan cuci tangan secara efektif sebelum membantu ibu melakukan IMD. Kemudian peneliti memasang alat perlindungan diri sebelum melakukan tindakan. Sebelumnya meminta persetujuan terlebih dahulu kepada ibu untuk dilakukan IMD. Dimulai setelah bayi lahir meletakkan bayi di perut ibu, lalu menilai bayi apakah diperlukan resusitasi atau tidak ( 2 detik), Bila tidak perlu resusitasi, mengeringkan tubuh bayi mulai dari muka, kepala, dan bagian tubuh lainnya dengan halus kecuali tangan karena bau cairan amnion pada tangan bayi membantunya mencari puting ibunya yang berbau sama. Setelah itu, menyelimuti bayi dengan kain kering untuk menunggu 2 menit sebelum tali pusat di klem. Menghindari mengeringkan tangan bayi, lendir cukup di lap dengan kain bersih, penghisapan tidak dilakukan karena dapat merusak selaput lendir dan dapat meningkatkan resiko infeksi pernafasan. Meletakkan bayi tengkurap didada ibu langsung dengan melakukan kontak kulit ke kulit, luruskan bahu bayi sehingga bayi menempel di dada ibu, tapi lebih rendah dari puting. Kemudian menyelimuti ibu dan bayi dengan kain hangat dan pasang topi di kepala bayi. Biarkan bayi tetap melakukan kontak kulit ke kulit di dada ibu paling sedikit 1 jam, mintalah ibu untuk memeluk dan membelainya bayinya. Lalu meletakkan bantal dibawah kepala ibu untuk mempermudah kontak visual antara ibu dan bayi. Bayi memperlihatkan perilaku dalam 30 menit pertama diam tidak bergerak dan matanya membuka lebar,pada 35 menit bayi mengeluarkan suara, mulut seperti ingin minum, mencium, dan menjilat tangan lalu mengeluarkan air liur, 45 menit bayi mulai bergerak kearah payudara ibu, saat menemukan, menjilat, mengulum puting dan mulutnya membuka lebar dan melekaat dengan baik, serta posisi bayi benar, kemudian bayi 
menyusui selama 10 menit lalu berhenti menyusu, posisi bayi saat menyusu dalam keadaan benar. Kemudian saat ibu melakukan IMD peneliti memperhatikan kondisi ibu dan bayi yang terlihat tenang dan nyaman. Sehingga memudahkan peneliti dan observer melakukan penilaian.

Setelah selesai dilakukan Inisiasi Menyusu Dini selama 55 menit, peneliti memberitahukan kepada ibu bahwa IMD selesai dilakukan dan bayinya akan dilakukankan asuhan bayi baru lahir normal. Peneliti membereskan alat dan perlengkapan lainnya.

\section{d. Evaluasi}

Setelah dilakukan pelaksanaan Inisiasi Menyusu Dini klien merasa ASI nya masih sedikit keluar. Oleh karena itu peneliti memberikan konseling tentang pemberian ASI selanjutnya dan tetap memberikan ASI kepada bayi. Menurut JNPK-KR (2008) Rangsangan isapan bayi pada puting susu ibu akan diteruskan oleh serabut syaraf ke hipofise anterior untuk mengeluarkan hormon Prolaktin. Hormon ini yang memacu payudara untuk menghasilkan ASI. Semakin sering bayi menghisap puting susu akan semakin banyak prolaktin dan ASI dikeluarkan. Pada hari-hari pertama kelahiran bayi, apabila penghisapan puting susu cukup adekuat maka akan dihasilkan secara bertahap $10-100 \mathrm{ml}$ ASI. Produksi ASI akan optimal setelah hari $10-14$ usia bayi. Bayi sehat akan mengkonsumsi $700-$ $800 \mathrm{ml}$ ASI perhari (kisaran 600-1000 ml) untuk tumbuh kembang bayi. Selain itu, jangan berikan makanan atau minuman lain kepada bayi (misalnya air, madu, larutan gula, atau pengganti susu ibu), berikan ASI eksklusif selama enam bulan pertama hidupnya, serta berikan ASI pada bayi sesuai dorongan alamiahnya baik siang maupun malam (8-10 kali atau lebih dalam 24 jam) selama bayi menginginkannya.

Selain itu, peneliti juga memberikan pendidikan mengenai perawatan payudara dan persiapan memperlancar pengeluaran ASI agar klien mengetahui jika sewaktu - waktu bayi mengalami kesulitan untuk mendapatkan ASI. Hal ini sesuai menurut Sitti Saleha (2009) yaitu dengan membersihkan puting susu dengan air atau minyak agar puting susu bersih, dan mengeringkan puting tanpa menggunakan kain untuk mencegah lecet, tarik puting susu setiap mandi, sehingga menonjol untuk memudahkan isapan bayi. Puting susu dalam mulut bayi dapat membuat rangsangan yang lebih mantap sehingga refleks pengeluaran ASI lebih sempurna. Oleh karena itu, perhatikan apakah klien telah menyusui pada posisi yang benar dan ajarkan untuk mengeluarkan ASInya sedikit lalu dioleskan keputing susunya, keringkan puting susu sebelum menggunakan pakaian.

ASI Eksklusif adalah pemberian air susu ibu saja kepada bayi tanpa memberikan cairan lain seperti susu formula, jeruk, madu, air teh, air putih dan makanan tambahan padat seperti pisang, pepaya, bubur susu, biskuit, bubur nasi dan nasi tim. Sesuai dengan pedoman internasional, ASI Eksklusif diberikan hingga bayi berusai 6 (enam) bulan karena secara ilmiah dapat dibuktikan bahwa ASI sangat besar manfaatnya bagi bayi dan semua energi dan nutrisi yang dibutuhkan bayi dapat tercukupi hanya dengan pemberian ASI Ekslusif hingga usia bayi 6 (enam) bulan. Pemberian ASI Eksklusif dapat mengurangi angka kematian bayi karena berbagai penyakit yang sering diderita anak-anak misalnya diare dan radang paru. ASI Eksklusif juga dapat mempercepat pemulihan bayi setelah sakit dan dapat membantu menjarangkan kehamilan (Linkages, 2002).

Adapun cara pengukuran berat badan bayi untuk mengetahui adanya peningkatan berat badan bayi dengan melakukan pemeriksaan kembali, bayi ditimbang kembali pada hari ke - 3 saat masih di Klinik Bersalin Budi Medika Palembang dan pada kunjungan ulang ke rumah hari ke -7 .

Pada hari ke-3 setelah dilakukannya IMD, peneliti klien mengaku merasa masih sedikit ASI yang keluar, tapi tetap memberikan ASI secara eksklusif tanpa mengganti dengan makanan tambahan lainnya, berat badan bayinya pun bertambah dari 3100 gram menjadi 3250 gram. Menurut Sitti Saleha (2009) Penyediaan berlangsung terus sesuai kebutuhan, pengisapan bayi akan memberikan rangsangan yang jauh lebih besar. Kemudian peneliti dan observer memeriksa klien, produksi ASI lancar, lanjutkan pemberian ASI.

Setelah 1 minggu klien mengaku senang karena sekarang produksi ASInya semakin bertambah banyak, dan tetap memberikan ASI secara eksklusif, serta berat badan bayinya juga semakin bertambah menjadi 3400 gram".

\section{KESIMPULAN}

Berdasarkan hasil penelitian dan pembahasan dapat ditarik kesimpulan sebagai berikut : Posisi bayi saat menyusui dalam keadaan benar saat dilakukannya proses Inisiasi Menyusu Dini. Proses pemberian ASI secara eksklusif berjalan dengan baik setelah dilakukan IMD walaupun penelitian dilakukan dalam batas 
Jurnal Kebidanan :Jurnal Medical Science Ilmu Kesehatan Akademi Kebidanan Budi Mulia Palembang Volume.10 No.2, Desember 2020

waktu tertentu. Pada hari ke-3 berat badan bayi bertambah dari 3100 gram menjadi 3250 gram, dan pada hari ke-7 berat badan meningkat menjadi 3400 gram. Pelaksanaan metode IMD sesuai dengan prosedur yang ada dan di observasi oleh observer menggunakan check list untuk mengetahui kesalahan peneliti.

\section{DAFTAR PUSTAKA}

Aprilia, Y, 2010. Analisis Sosialisasi Program Inisiasi Menyusu Dini Dan Asi Eksklusif Kepada Bidan Di Kabupten Klaten [Tesis] Program Pasca sarjana Universitas Diponegoro Semarang http://eprints.Undip.ac.id/,

Aziz Alimul Hidayat, 2007. Metode Penelitian Kebidanan dan Teknik Analisis Data. Salemba Medika. Jakarta.

Azwar, Azrul, 2007. Asuhan Persalinan Normal dan Inisiasi Menyusui Dini. Jakarta: JNPK-KR.

Dinkes Sumsel, 2005. Profil Dinas Kesehatan Sumatera Selatan. Dinkes Sumsel. Sumatera Selatan.

Eny. R, Diah. W, 2009. Asuhan Kebidanan Nifas. Mitra Cendikia. Yogyakarta

JNPK-KR, 2007, Jaringan Nasional Pelatihan Klinik-Kesehatan Reproduksi (JNPK-KR), 2007. Jakarta

Keputusan Menteri Kesehatan Republik Indonesia No .900 /MENKES/ SK/ VII/2002 tentang Registrasi dan Praktik Bidan

Kementerian Kesehatan RI Pusat Data dan Infomaso.2018.Menyusui Sebagai Dasar Kehidupan.Tema Pekan ASI Sedunia, 1-7 Agustus 2018.

Khairuniyah, 2004. Pemberian ASI Ekslusif ditinjau dari faktor motivasi, persepsi, emosi dan sikap pada ibu yang melahirkan. Tesis. Bandung. Universitas Padjadjaran. Available at : http://www.pustaka.unpad.ac.id.

Linkages. 2002. "Pemberian ASI eksklusif Atau ASI saja:Satu-satunya Sumber Cairan Yang Dibutuhkan Bayi Usia Dini”.
Available

at

http://www.linkages.project.org.

Manuaba, I.B.G, 2008. Ilmu Kebidanan, Penyakit Kandungan dan KB. EGC. Jakarta. Available at : http:// repository.usu.ac.id.

Minarto, 2010. Jalan Cerdas Menuju Sehat. Available at : http://www. gizi.depkes.go.id.

Nanny, Vivian, 2010. Asuhan Neonatus Bayi dan Anak Balita. Salemba Medik. Jakarta

Notoatmodjo, S, 2007. Promosi Kesehatan dan Ilmu Perilaku, Rineka Cipta, Jakarta Nusantara. Available at : http://www.repository.usu.ac.id.

Nurhaida Br Kaban.2017.Inisiasi Menyusu Dini. Jurnal Keluarga Sehat Sejahtera.Vol.15 (2) Desember 2017.

Peraturan Menteri Negara Pemberdayaan Perempuan dan Perlindungan Anak, 2010, Penerapan Sepuluh Langkah Menuju Keberhasilan Menyusui,Jakarta. Available at : www.menegpp.go.id.

Roesli. 2008. Mengenal ASI Exklusif. Jakarta : Pustaka Pengembangan Swadaya

Rohani, Reni Saswita, Marisah, 2011. Asuhan Kebidanan Pada Masa Persalinan. Salemba Medika. Jakarta.

Saleha, Sitti, 2009. Asuhan Kebidanan Pada Masa Nifas. Salemba Medika. Jakarta

Suraatmaja S. Aspek Gizi Air Susu Ibu. Dalam: ASI Petunjuk Untuk

Suyanto. 2006. Pedoman Pelaksanaan Penelitian Tindakan Kelas (PTK) Bagian. Pertama Pengenalan Penelitian Tindakan Kelas. Yogyakarta : Depdikbud available at : http:// www. repository.upi.edu.

Utami, Roesli. 2004. ASI Eksklusif. Edisi II. Jakarta : Trubus Agrundaya. Available at : http://www.repository.usu.ac.id, 2010. 
